\author{
EMERGING VOICES
}

\title{
The Transnational Self across Borders: A Comparative Study of Kiran Desai and Chimamanda Ngozi Adichie
}

\author{
Nada Ghazy*
}

Growing numbers of writers are 'on the move' and travel outside their native cultures and homelands. Globalization, colonization, and mobility caused multicultural encounters among subjects, raising issues related to border crossings. While moving across the globe and in between different cultures and nations, individuals find themselves more apt to embrace opportunities of freedom that mobility is able to grant them. Identities are continuously producing and reproducing different versions of themselves according to the shifting locations and multiple existences they embody. The postmodern identity is in a constant mode of becoming. This paper highlights the construction and malleability of the transnational self across borders through examining two novels, namely Kiran Desai's The Inheritance of Loss (2006 [2007]), and Chimamanda Ngozi Adichie's Americanah (2013 [2017]). These two novels are examined and read from a transnational perspective since concepts such as migration, mobility, and colonization are highlighted throughout. Since both novels deal with the concept of migration explicitly, this paper addresses how migration may affect or change the subject, how characters may or may not develop a malleable and hybridized identity, and how living in-between cultures affects the characters' position and vision. Transnational scholars and theorists explain that identity is fluid rather than fixed, and transnationalism believes that individuals exist beyond the nation-state. Transnational mobility highlights cross-border connections and goes against essentialist views, promoting and emphasizing difference. Since identities are in constant movement and are considered fluid and malleable, identities progress and transform in relation to

\footnotetext{
* Independent researcher. This paper is derived from her $\mathrm{Ph} . \mathrm{D}$. thesis in-progress, entitled "The Malleability of the Gendered Self across Borders: A Comparative Study of Assia Djebar, Kiran Desai, and Chimamanda Ngozi Adichie" (Cairo University), supervised by Prof. Shereen Abouelnaga.
}

Cairo Studies in English 2020(2): https://cse.journals.ekb.eg/ 
the places they travel to. Transnationalism highlights cross-border connections and explains how people and cultures are connected across borders.

In The Grammar of Identity: Transnational Fiction and the Nature of the Boundary, Stephen Clingman explains that "transnational fiction is written by, and directed towards, migrant and multi-lingual communities who exist in multiple and in-between spaces. It is, in essence, a migrant and migrating literature" $(2012,8)$. From a fictional as well as a theoretical point of view, the present interest in mobility is a result of the increasing relevance of postcolonial discourses and the continuous process of globalization, which has resulted in a re-conceptualization of identity and location. Arianna Dagnino explains,

we have entered an age of "global uncertainty" and "liquid times" in which fixed points of reference vanish, boundaries fade, cultural edges blur and (im)migration (imposed or chosen), movement, and voluntary or involuntary displacement become a common trait for growing numbers of people [...] people throughout all layers of society are on the move across the planet and experience the effects of dislocation. (2013, n. pag.)

Moreover, Dagnino also explains that "mobility in all its variants - international, professional and leisure travel, diasporas, forced or voluntary (im)migrant labor, elite frequent flying - has become the trope of societies" (2013, n. pag.). Thus, mobility suggests a loosening of identity constraints and opens new dimensions in an individual's identity when they cross borders.

In an increasingly multicultural world that is governed by transnational ideas, identities are shaped through mobility and travel, often resulting in the formation of a hybridized and hyphenated identity. Mobility allows subjects to defy an attempt to be merely defined by a certain geographic location or ideology, and movement in the selected texts provides a means to represent these malleable and hybrid identities. The characters in both novels encounter at least two cultures, and their mobility may or may not lead to the formation of a hybrid identity. In "Hybridity, Why It Still Matters," Vanessa Guignery defines hybridity and explains that

postcolonial theory adopted the idea of hybridity to designate the transcultural forms that resulted from linguistic, political or ethnic intermixing, and to challenge the existing hierarchies, polarities, binarisms, and symmetries (East/West, black/white, 
colonizer/colonized, majority/minority, self/other, interior/exterior). [...] Hybridity stands in opposition to the myth of purity and racial and cultural authenticity, of fixed and essentialist identity, embraces blending, combining, syncretism and encourages the composite, the impure, the heterogeneous and the eclectic. $(2011,3)$

Thus, hybridity basically presents itself as a discourse that challenges essentialist views and the idea of a dominant and fixed culture.

Homi Bhabha, a principal theorist of hybridity, claims that the movement between nations causes individuals to end up in-between cultures, developing a hybrid identity within a 'third space'. Bhabha explains that crossing a border puts an individual in "the moment of transit where space and time cross to produce complex figures of identity, past and present, inside and outside, inclusion and exclusion" (1994, 1-2). In an interview conducted by Jonathan Rutherford, Bhabha explains that "all forms of culture are continually in a process of hybridity" and he goes on to clarify that

the importance of hybridity is not to be able to trace two original moments from which the third emerges, rather hybridity to me is the "third space" which enables other positions to emerge. This third space displaces the histories that constitute it, and sets up new structures of authority, new political initiatives, which are inadequately understood through received wisdom. $(1990,211)$

It is apparent that hybrid identities may begin to surface due to colonization and the movement between cultures. Bhabha explains that the increasing occurrence of these hybrid identities places individuals in an in-between space where individuals are "neither the One [...] nor the Other [...] But something else besides which contests the terms and territories of both," and this is what Bhabha means by the term third space $(1994,41)$. Thus, it can be concluded that hybridity leads to the creation of something new, a 'third space', where different cultures interlock and where different cultural identities are continually being formed, reformed, and are constantly in a state of becoming. Third space is a place where hybrid identifications are formed, where interchanges between different cultures evolve, and is a place where new qualities come to existence. Bhabha highlights how mobility and colonization cause identity to be placed within a liminal space or a third space rather than confined to one nation or one culture. He explains that the third space "opens up the possibility of a cultural 
hybridity that entertains difference without an assumed or imposed hierarchy" $(1994,5)$. Bhabha further explains that occupying a third space "gives rise to something different, something new and unrecognizable, a new area of negotiation of meaning and representation," which highlights the fact that hybridity and third space go against essentialism $(1990,211)$.

Through Bhabha's explanation, it is clear that cultures and identities are no longer pure or inherited from tradition. Instead, new 'in-between' and hybrid identities are being forged within a new space when two different cultures intertwine. Bhabha further explains, "these new in-between spaces provide a terrain for elaborating strategies of selfhood [...] that initiate new signs of identity and innovative sites for collaboration and contestation" $(1994,2)$. Moreover, Edward W. Soja defines third space as

a space of extraordinary openness, a place of critical exchange where the geographical imagination can be expanded to encompass a multiplicity of perspectives that have heretofore been considered by the epistemological referees to be incompatible, uncombinable. It is a space where issues of race, class, and gender can be addressed simultaneously without privileging one over the other. $(2009,50)$

Thus, through Bhabha and Soja's definitions and explanations, it is apparent that the third space is a place where new forms of identities develop and where the hybrid nature of multicultural interactions is achieved.

In Reconstructing Hybridity: Post-Colonial Studies in Transition, Joel Kuortti and Jopi Nyman explain how postcolonial subjects go through a process of recasting their fixed identity:

The liminal space between the cultures of the colonizer and the colonized, migrants and other (post)colonial subjects go through a process that recasts their fixed sense of identity. While this reconstruction of identity may be positive and empowering, its transgressive character and location in the liminal space of borders and boundaries also, as Bhabha writes, poses potential dangers as it generates a new, hybrid subjectivity. Thus, to enter the Third Space, while it shows the potentiality of constructing a non-fixed identity, generates a new sense of identity that may resemble the old ones but is not quite the same. $(2007,8)$ 
Although occupying a third space may be positive and empowering, there are dangers and disadvantages that may occur in the process. Salman Rushdie also emphasizes how mobility causes the person to sometimes develop a double consciousness and he clarifies that mobility causes a person to

learn the new ways of a community, [and] is forced to face the great questions of change and adaptation; but many migrants, faced with the sheer existential difficulty of making such changes, and also, often, with the sheer alienness and defensive hostility of the peoples amongst whom they find themselves, retreat from such questions behind the walls of the old culture they have brought along and left behind. $(2003,82)$

Rushdie explains how mobility may affect the identity in different, perhaps negative ways, where they hurry and hide "behind the walls of old culture," which results mainly from geographical and cultural dislocation (2003, 82). Rushdie explains that mobility may affect a person in a negative way when an individual is resistant to change and clings to their own culture instead of having an open mind to acquire new traits from a new culture. This resistance to change is seen through a character named Biju in The Inheritance of Loss.

In The Inheritance of Loss, Kiran Desai is concerned with the migration of characters from their South Asian homeland to England and the United States and is also concerned with the characters in India who are influenced by the British culture. Kiran Desai is an Indian author who left her homeland, India, at the age of fourteen, and lived in England and then moved permanently to the United States. The novel contains two interconnected narratives: the first is set in New York and explores the effect of globalization on migrant workers while the other is set in India and analyzes the effects of colonization on its characters. All the characters in Desai's novel, whether in New York, England, or India, find themselves located between at least two cultures, and throughout the novel, we can see both the potentials and the pitfalls of the modern, hybrid, and malleable identity.

In The Inheritance of Loss, Kiran Desai is concerned with the concept of migration and with what it means to live in a post-colonial setting. Mobility is discerned in the novel's interconnected stories of migration: the story of Jemubhati Patel, the judge or Jemu in short, who leaves India in 1939 to pursue a higher education at Cambridge, which Desai portrays in her novel through flashbacks, and the story of Biju, an Indian illegal immigrant in the United 
States. These two narratives are linked to the story of the Nepali-Indian minority, who demand statehood in the town of Kalimpong in the mid 1980's, and to Jemu's granddaughter, an orphan named Sai. Desai represents the mobility of her characters through employing a fragmented structure in her novel, a structure that shifts between different times and spaces, using a gloomy tone in order to show that immigration is a difficult movement between home and the host land.

Both Jemu and Biju emigrate from their country of origin, India. However, due to the difference in social class and legal status, Biju and Jemu's experiences in their host countries are very different. In "Identity and Migration: An Introduction," La Barbera explains that "faced with an unknown universe of meanings, migrants feel lost, alone, and without reference points. As much as they strive to become integrated, migrants remain strangers. Moreover, migrants face distrust and hostility" $(2015,3)$. This can be clearly applied to both characters, Biju and Jemu. In The Inheritance of Loss, it can be argued that Jemu and Biju's mobility and immigration have a limited transformative potential in their host countries since "[n]either the judge nor Biju achieved social or financial success abroad, and both created exaggerated, rigid identities for themselves- either pure English or Indian" (Speilman 2010, 88).

Biju, the son of Jemu's cook, who immigrates to the United States to escape his poverty is an example of how mobility has an inadequate impact. Kiran Desai outlines themes of dislocation and yearning for home through the character of $\mathrm{Biju}$. He is considered to be the perfect example of the character who hurries to hide "behind the walls of old culture" and who refuses to become a hybrid and to let go of his own heritage and origin (Rushdie 2003, 82). Biju is an illegal immigrant who is exploited in the kitchens of New York and finds it impossible to adjust to the American culture. Working in a restaurant in New York and serving meat goes against Biju's principles and religion and this is clearly portrayed when he states, "Holy cow unholy cow. Job no Job. One should not give up one's religion, the principles of one's parents and their parents before them. No matter what" (Desai 2007, 135-36). It is clear that Biju experiences a fear of losing India and his identity throughout his stay in the United States, and so he decides to stand by his cultural and religious principles and finds another job in an Indian restaurant, Gandhi Café, owned by an Indian who goes by the name Harish-Harry.

In "Migration, Globalization, and Divided Identity in Kiran Desai's The Inheritance of Loss, " Kondali explains that, 
Biju's sense of self and his cultural awareness are under pressure to westernize, which in turn triggers his struggle to resist. His awareness of himself becomes deeply shaken, driven by painful displacement not only from his homeland, family and culture, but from his previous understanding of his individual and collective belonging. $(2018,109)$

It is apparent that Biju resists embracing a hybrid identity and does not want to adapt to the American culture in any way. During his stay in the United States, he only dreams of his homeland, and makes sure that he does not lose the Indian cultural values that are instilled within him. Dagnino argues that "being on the move is not enough if there is not the willingness, the curiosity, the disposition, the (cultural/material) means, the sensibility, and in general, an 'expansive orientation' to open oneself to the Other and participate in, be involved with the culture/s of the Other" (2013, n. pag.). Biju does not have the willingness nor the curiosity to open himself to the American culture and refuses to be involved in it in any way. When Biju decides to go back to India, the Nepali radicals rob him of everything on his way back home: his clothes, his wallet, his shoes, his belt, his jacket, his jeans, and his T-shirt (Desai 2007, 317). Biju returns to India "without his baggage, without his savings, worst of all, without his pride. Back from America with far less than he'd ever had," which highlights how Biju's mobility was in no way groundbreaking (317). Although Biju returns to India without his pride and with far less than he ever had, it is clear that he still feels very relieved to be back to his hometown:

Biju stood there in that dusty tepid soft sari night. Sweet drabness of home - he felt everything shifting and clicking into place around him, felt himself slowly shrink back to size, the enormous anxiety of being a foreigner ebbing - that unbearable arrogance and shame of the immigrant. No body paid attention to him here, and if they said anything at all, their words were easy, unconcerned. He looked about and for the first time in God knows how long, his vision unblurred and he found that he could see clearly. (300)

It is evident that when Biju returns to his hometown he feels calmer and a sense of relief dawns upon him. This proves that Biju is a rooted individual, and all along, he never accepted being a hybrid, only wanting the Indian culture to be infused within him. 
In relation to hybridity, the dichotomy between 'routes' and 'roots' cannot be overlooked since it explores the complex relationship between the homonyms in the process of identity formation. Through mobility and migration, individuals are positioned at the transnational spaces of nations, and hybrid identities are reproduced as a product of several intertwined histories, cultures, and societies. This may either lead to discarding your own 'roots,' rejecting the 'route' one takes, or in some cases, may lead to the emergence of the hybrid self. Regardless of the outcome, identity still exists in a tension and mediation between 'roots' and 'routes.'

In "Roots and Routes: Exploring the Relationship Between Place and Attachment and Mobility," Per Gustafson explains that "roots has long been an important metaphor for place and attachment in Western society [...] It is part of a metaphorical system linking people to place, identity to territory. In this context, roots signify emotional bonds with the physical environment but also contains notions of local community, shared culture, and so forth" $(2001,670)$. Gustafson clarifies the concept of 'routes' as well, and explains that "this concept points towards [people's] mobility, their movements, encounters, exchanges, and mixtures" (2001, 670). Thus, 'roots' refers to how individuals identify themselves within their country of birth and refers to the authentic home and origin culture, whereas, 'routes' involves movement, mobility, immigration, and change. Moreover, the term 'route' recognizes the fluidity and flexibility of identity and how one's identity changes over time, depending on what path an individual takes. Susan Friedman explains that "roots and routes are, in other words, two sides of the same coin: roots signifying identity based on stable cores and continuities; routes, suggesting identity based on travel, change, and disruption" $(1998,153)$. Since a rooted identity is rather essentialist, many theories such as Gayatri Chakravorty Spivak, David Moore, and Susan Friedman celebrate hybridity and the concept of 'route' since they all believe that the formation of identity transcends national boundaries.

In "Routes," David Moore explains that "we need to talk not about roots but about routes: trajectories, paths, interactions, links. This root itself is not a bad, false, or wrong story. It is rather a narrowly true narrative in the midst of a broader and more tangled truth, or richer story" $(1994,21)$. In The Post-Colonial Critic, Spivak states in an interview, "One is always on the run, and it seems I haven't really had a home base- and this may have been good for me. I think it's important for people not to feel rooted in one place" $(1990,37)$. Moreover, in Mappings, Friedman states: 
Identity developed through routes involves an experience of leaving roots, of moving beyond the boundaries of "home" (however that is defined or problematized). A geopolitical identity rooted in "home" insists upon sameness within the home circle; one formed through leaving home base involves interaction with others, which fosters the formation of hybridic combinations. $(1998,154)$

Friedman further emphasizes that "narratives about identity and the identity of narrative itself involve an underlying dialogic negotiation between the assertion of difference (roots) and the acceptance of hybridity produced through travel in time and space (routes)" $(1998,11)$. The interplay between 'roots' and 'routes' in the two novels is very evident and can be seen through the characters since some of them embrace their hybridity and go on different routes, while others resist change and only feel rooted in one location. As seen through Biju's character, he is considered to be rooted in one location, India, and resists the 'route' he took to the United States. Mobility and border crossing affect characters in very different ways; however, it is possible to argue that it has stark effects on their identity formation. Most of the characters in the novels suffer from an identity crisis caused by mobility, colonization, and displacement; hence the malleability of the self is an essential tenet of the 'becoming' process.

Jemu is considered to be an impoverished student in England, who eventually returns to India, and in the process, transforms into an Anglicized individual who discards his family and native culture, choosing instead a life based on a fixated quest for insincere colonial ideals. Jemu leaves his fourteen year old wife, Nimi, and his ancestral home Piphit and "from there he had journeyed to the Bombay dock and then sailed to Liverpool, and from Liverpool he had gone to Cambridge" to continue his studies (Desai 2007, 35). In Cambridge, Jemu's days were filled with racism and loneliness where "girls held their noses and giggled, 'Phew, he stinks of curry!'” (39). Moreover, during his stay in England, Jemu stopped talking in the first person, and the narrator states, "He had learned to take refuge in the third person and to keep everyone at bay, to keep even himself away from himself" (111). This led Jemu to become a stranger to himself where he eventually "found his own skin odd-colored, his accent peculiar [...] He began to wash obsessively, concerned he would be accused of smelling, and each morning he scrubbed off the thick milky scent of sleep, the barnyard smell that wreathed him when he woke" (40). During his stay in England, Jemu develops a craze for the Western culture, and Kondali explains that "once away from India, [Jemu] undergoes an educational and cultural transformation in England 
that has a profound impact on his identity: he confines himself to his room, lets his landlady call him James, and becomes embarrassed by his unpronounceable name, his pronunciation of English, and the color and smell of his skin" (2018, 110). Unlike Biju, Jemu tries to run away from his roots.

When Jemu returns to his homeland, India, it is apparent that he has become negatively obsessed with his Indian identity, which is evident as he continually tries to wash himself over and over again, and begins using white powder to hide his Indian features. Desai explains that Jemu's "face seemed distanced by what looked like white powder over dark skin," revealing his insecurities and the way he wants to get rid of his Indian identity $(2007,33)$. Moreover, Jemu clings to his English identity when he returns to India since he believes that clinging to Western ideals will elevate him above others in the community. In the novel, the narrator explains that Jemu "could live here, in this shell, in this skull, with the solace of being a foreigner in his own country" because "English was better than Hindi" (29-30). Jemu is obsessed with Western values, manners, and language and Desai clearly portrays that in her novel when she explains that "[Jemu] envied the English. He loathed Indians. He worked at being English with the passion of hatred and for what he would become, he would be despised by absolutely everyone, English and Indians, both" (119). Jemu was a lost individual who wanted to mimic the West and tried his utmost best to detach himself from his own origin, culture, and roots.

Thus, La Barbera explains that a migrant's position is "in between, at the borderland, in transit. The process that begins when one leaves his/her country never ends, and it generates an unfinished condition of not yet belonging 'here' but no longer 'there,"' which is clearly applicable to Jemu's case $(2015,3)$. The reason why Jemu's immigration may be viewed in a negative manner is because he is depicted in the novel as an individual who continually tries to separate himself from his roots and desperately attempts to run away from his Indian heritage. Oana Sabo argues that "the tension between local and global cultures is further explored through the depiction of an anachronistic Anglophile elite. On the higher end of the hierarchal scale is the misanthropic Judge Patel, whose admiration for the English [...] renders him 'a foreigner in his own country"" (2012, 383). Moreover, “The judge's anglophilia marks him as a particular kind of postcolonial subject: a self-hating Indian, a would-be Englishman, a foreigner to everyone including himself" (Speilman 2010, 77). Jemu suppresses his Indian identity and at the same time cannot be considered English; thus he refuses to embrace his hybridity and rather focuses on impersonating merely the English identity. Speilman then compares both Biju and Jemu and states, "whereas the 
judge eschews what he has learned in India when he leaves and constructs solid knowledge from firsthand experiences abroad, Biju rejects firsthand experience and clings to his established beliefs," emphasizing the difference between both characters $(2010,78)$. It is clear that neither Biju nor Jemu's mobility are transformative in any manner since Jemu becomes an Anglicized Indian who develops a craze for the West, whereas Biju resists the American culture, and refuses to adapt to it, and so they both become resistant to the idea of developing a hybrid self.

Jemu and Biju's mobility is depicted in a negative manner since their mobility leads them to develop a fixed identity. Jemu comes back to his country with a negative attitude, trying to escape his own Indian heritage and attempting to mimic the West instead, whereas, Biju fails to adapt to the American culture, develops a rigid identity, and returns to India "with far less than he'd ever had" (2007, 317). Jemu, rejects his Indian heritage, culture, and roots and only allows the English culture to be infused within him. He is unable to accept the presence of his native culture and roots and, at the same time, cannot be considered to be purely English; thus, he is displaced from both cultures and becomes a stranger to everyone. Biju, unlike Jemu, rejects another culture taking over, and dreams and wishes to go back to his country of origin. Biju does not believe in adopting a new identity and wants to "hold on to a one-dimensional and immutable Indian identity because it safeguards him from "contradictions" (Winden 2015, 52). Biju's response to hybridity suggests that he prefers to stay loyal to his own culture, to his own roots; thus, one can infer that both Biju and Jemu reject hybridity and transnationalism and instead adopt a singular culture, but in Biju's case, he chooses only the Indian culture to be infused within him, whereas Jemu chooses the English culture.

In Globalization and the Postcolonial World, Hoogvelt argues that cultural hybridity is "celebrated and privileged as a kind of superior cultural intelligence owing to the advantage of in-betweenness, the straddling of two cultures and the consequent ability to negotiate the difference" $(2001,158)$. The reason why many theorists celebrate the concept of hybridity is because it can be seen as an antidote to essentialism and because it empowers individuals since subjects undergo a process that recasts their identity. It is also explained that "as a product of belonging to multiple affiliations, the hybridization of being at the borderlands poses serious challenges to the existing hegemonic culture of society," which shows how hybridity helps in dismantling essentialism and hegemony (La Barbera 2015, 5). Similarly, Susan Friedman explains that "hybridity is transgressive, a creative force that disrupts, denaturalizes, and potentially 
dismantles hegemonic cultural formations" $(2002,8)$. Thus, the possibility of difference that hybridity proposes involves multicultural interactions where concepts like identity and space are defined as malleable rather than static and fixed. However, Samir Dayal criticizes the concept of hybridity and states that his attempt and goal "is to conceive doubleness negatively, to explode the positive and equilibristic constructions of diaspora around the desire of belonging ideally to two or more places or cultures. That 'doubleness' is often laced with nostalgia, filial piety, and credulity. It is hardly a space within which a salutary rhetoric of suspicion can flourish" $(1996,47)$. Dayal further explains that "its negative value is that it denies the subject's sovereignty and stresses the performativity of the subject" (48). Thus, it is clear that there are many critics who celebrate hybridity and others who criticize the concept itself claiming that it denies the subject's autonomy.

An example of a hybrid identity in The Inheritance of Loss would be Biju's colleague and friend, Saeed Saeed, a minor character in the novel. Saeed executes multiple identities that instigate from both his cultural roots and mindful choices. Saeed is a Muslim from Zanzibar who lives in the United States, and refuses to eat pork due to his religious affiliations. He tells Biju, "First I am a Muslim, then I am Zanibari, then I will BE American" (Desai 2007, 136). It is evident that Saeed acknowledges his multiple identities and has no problems with them. Throughout the novel, we do not see Saeed as someone who clings to his origin nor does he cling to the culture of his host country; he is a mixture of all cultures and a proper hybrid. Speilman argues that "Saeed does not strive after solid knowledge the way Biju does, not does he resist change. His success derives primarily from his ability to adapt to the cultural context in which he finds himself" $(2010,79-80)$. Saeed is considered to be a flexible and malleable character who adapts to the American culture, and this is highlighted when the narrator states, "he relished the whole game, the way the country flexed his wits and rewarded him; he charmed it, cajoled it, cheated it, felt great tenderness and loyalty toward it" (Desai 2007, 79). Also, Saeed reads a self-help book and tells Biju, "Now you are here, you are not back home. Anything you want, you try and you can do" (190). Saeed does not allow anything to stop him from being who he wants to become and develops a malleable identity.

While Biju finds love for his Indian culture in the United States of America, and Jemu finds love for the English culture in England, Sai, Jemu's granddaughter, seems to accept her hybridity. Sai seems to be more aware of her Western traits and upbringing in India since she was brought up by English nuns. Sai's parents both die and she grows up as a Westernized Indian; however, 
despite that, Sai never becomes an anglophile and embraces both her Indian and English personas. When we first encounter Sai in the novel, she was "reading an article about a giant squid in an old National Geographic" (Desai 2007, 1). Although Sai is reading an English magazine in her home in India, she "does not strictly fall into a Western or Eastern Category" (Hooda 2014, 33). She may be labeled as a Westernized Indian; however, she does not choose to cling to one of the cultures like Jemu or Biju. When she falls in love with Gyan, her Nepali math tutor, she is provoked by his assertions that she is a servant of the West. Gyan tells Sai:

You are like slaves, that's what you are, running after the West, embarrassing yourself. [...] Can't think for yourself. Copycat, copycat. Don't you know these people you copy like a copycat, THEY DON'T WANT YOU!!!. (Desai 2007, 163-164)

To further prove his point, Gyan asks Sai, "Why do you celebrate Christmas? You're Hindus and you don't celebrate Id or Guru Nanak's birthday or even Durga Puja or Dussehra or Tibetan New Year" (163). However, Sai does not back off and tells him in an assertive tone, "If I want to celebrate Christmas, I will, and if I don't want to celebrate Diwali then I won't. Nothing wrong with a bit of fun and Christmas is an Indian holiday as much as any other" (163). Sai embraces her hybridity, and this is very evident from the way she responds to Gyan's criticism. She wants to celebrate Christmas whenever she wants to, and at the same time, she is never bothered by her Indian heritage. Speilman argues that:

Sai, however, responds to this westernizing very differently from the way that her grandfather had. She does not become an anglophile, despising Indian things and attempting to elevate herself by fashioning an exclusively western identity. She adopts an ambivalent mindset towards her potentially contradictory desires. She wants English but also Indian things. $(2010,83)$

Sai embraces both her Indian and English sides equally even though English nuns raised her as a Westernized Indian.

Towards the end of the novel, Sai thinks "of all the National Geographics and books she had read. Of the judge's journey, [...] of Biju's. Of the globe twirling on its axis. And she felt a glimmer of strength. Of resolve. She must leave" 
(Desai 2007, 323). Sai realizes that she needs to move away from India, to explore herself in other locations, thus showing how Sai advocates movement and mobility and realizes that India is too small for her and that her life could be anchored in many locations. Hooda explains that "Sai's identity, unlike other characters, is the least culturally conflicted, despite being so Westernized in her little Indian village. [...] Unlike other characters in the novel, she does not differentiate between ideas of the East and West" $(2014,40)$. Sai, the grandchild of Jemu, exemplifies Bhabha's idea of a cultural hybrid since she "can remain in the Indian private sphere while still embodying an Anglicized lifestyle, because she is the result of the East and the West. [...] [Sai] is the cultural hybrid 'that entertains difference.' She represents postcolonial India as the result of combining the uncolonized with the colonized" (48). Sai does not see the difference between the East and the West because she is a descendant of both and decides to blur the two together as a hybrid, and enters the third space.

Chimamanda Ngozi Adichie's Americanah focuses on the concept of migration as well; however, the two protagonists in Americanah immigrate because they want to, not because of poverty as seen through Biju's case in The Inheritance of Loss. In Americanah, the two protagonists, Ifemelu and Obinze, meet and fall in love as students in their native land, Nigeria. They both separate and immigrate, Obinze to Britain, and Ifemelu to the United States. The novel begins as Ifemelu in her thirties is preparing to return to Nigeria, and the novel unfolds in a series of flashbacks. Both Ifemelu and Obinze immigrate due to the "oppressive lethargy of choicelesness" in Nigeria (Adichie 2017, 276). When Obinze is around his friends, he feels alienated because his migration story is unusual and different from the collective and usual ones that are driven by poverty and war:

Alexa, and the other guests, and perhaps even Georgina, all understood the fleeing from war, the poverty that crushed human souls, but they would not understand the need to escape from the oppressive lethargy of choicelessness. They would not understand why people like him, who were raised well-fed and watered but mired in dissatisfaction, conditioned from birth to look towards somewhere else, eternally convinced that real lives happened in that somewhere else. [...] None of them starving, or raped, or from burned villages, but merely hungry for choice and certainty. (276) 
Thus, it can be deduced that in the case of Obinze and Ifemelu, their migration is not caused by the common reasons, but was due to their need to experience more options and choices elsewhere. Francis B. Nyamnjoh explains that Africans are not mobile unless they are provoked or forced to move due to natural disasters:

Africans are not expected to be mobile, even as mobility is celebrated. The impression is given that Africans are mobile only when things go wrong or others so desire that they would ordinarily stay grounded, were it not for rapid population growth, economic stagnation, poverty, unemployment, conflicts and ecological disasters. Nothing African moves unless provoked by forces beyond their control. $(2013,659)$

However, Adichie depicts Africans who immigrate because they want to, because they are hungry for more choice, dismantling the stereotypical idea that Africans only migrate due to terrible conditions.

Throughout Adichie's novel, we find that the protagonist, Ifemelu, does indeed belong to more than one culture, and loses her fixed identity in the process, finding herself at some point alienated due to the clash of cultures. Moreover, in relation to the concept of hybridity, Simon Gikandi explains the concept of Afropolitanism in the Foreword of the book Negotiating Afropolitanism:

Afropolitanism may sound awkward as a term, but there is no doubting that it has been promoted by the desire to think of African identities as both rooted in specific local geographies but also transcendental of them. To be Afropolitan is to be connected to knowable African communities, nations and traditions; but it is also to live a life across cultures, languages, and states. It is to embrace and celebrate a state of cultural hybridity - to be of Africa and of the other worlds at the same time. $(2011,9)$

It can be stated that Ifemelu is an Afropolitan and a hybrid since she undergoes many changes in her identity and is situated between both the Eastern and Western cultures. We see Ifemelu as a native Nigerian, as an immigrant in the United States, and then she eventually transforms into a hybrid of both cultures. Ifemelu's identity has been influenced by both the Nigerian and American 
cultures and the title of the novel also signifies the hybridization of Ifemelu who eventually becomes an 'Americanah' or in other words Americanized. Ifemelu is presented as a migrant whose identity constantly changes, thus showing how mobility leads to the malleability of the self.

As soon as Ifemelu arrived to the United States, "she began to practice an American accent" (Adichie 2017, 134). Ifemelu's decision to practice the American accent depicts her linguistic hybridity and the malleability of her identity. Sackeyfio explains, "the act of speaking in a foreign voice marks the beginning of conscious doubling of [Ifemelu's] identity" (217). Another example of adapting to the American culture is when Ifemelu straightens her hair to look more American. Ifemelu was conversing with one of her friends about finding a job in the United States and Ruth advises her to lose her braids by saying, "My only advice? Lose the braids and straighten your hair. Nobody says this kind of stuff but it matters. We want you to get that job" (202). Ifemelu decides to go to a hairdresser and relax her hair, and after doing so the hairdresser tells her, "Wow, girl, you've got the white-girl swing!" (203). After Ifemelu leaves the hairdresser she feels down, and "she did not recognize herself. She left the salon almost mournfully; while the hairdresser had flat-ironed the ends, the smell of burning, of something organic dying which should not have died, had made her feel a sense of loss" (203). Although Ifemelu likes her original braided hair, she learns that she has to straighten it because the American society does not think braided hair is beautiful, and she has to adapt to her host culture. At this point in the novel, Ifemelu tries to adapt to the American culture and is somehow lost between both the Nigerian and American cultures.

Ifemelu modifies her physical appearance, her actions, and her voice to incorporate herself into the American social ambiance. She is caught between cultures, and "to live between cultures or languages is one important way of coping with the disorientation of moral geographies at the end of modernity" (Gikandi 2011, 10). It is clear that Ifemelu's manner of integrating herself into the American society and culture causes her to compromise and change who she really is. Although Ifemelu can be considered to be a hybrid, her sense of belonging towards Nigeria continually changes throughout the novel. In "Journey and Return: Visiting Unbelonging and Otherness in Adichie's Americanah" Soheila Arabian explains:

Ifemelu does not reveal any sense of belonging toward her motherland and she even looks for a way to leave; thus when she receives a scholarship, she leaves her country with a hope to 'prosper 
in America'. But after displacement, the situation changes and she faces a different life in America. Discrimination and racial issues alienate her as a black which brings her a sense of unbelonging towards America; consequently, she returns to her African origin and reveals her sense of belonging toward Nigeria. $(2015,538)$

Similar to Biju's case in The Inheritance of Loss, Ifemelu eventually longs for her homeland and feels she belongs to Nigeria after facing discrimination in the United States. After living in the United States for so long, "Nigeria became where [Ifemelu] was supposed to be, the only place she could sink her roots in without the constant urge to tug them out and shake off the soil" (Adichie 2017, 6). The noted difference between them is that Biju does not let the American culture penetrate him at all and that Ifemelu does adapt to the American lifestyle during her stay in the United States and develops a malleable and hybridized identity.

Towards the end of the novel, Ifemelu slowly makes a conscious decision to stick to her roots and origins and decides to leave her hair as is instead of straightening it. Ifemelu starts braiding her hair again and "on an unremarkable day of early spring ... she looked in a mirror, sank her fingers into her hair, dense and spongy and glorious, and could not imagine it any other way. That simply, she fell in love with her hair" (167). Moreover, she also "decided to stop faking an American accent on a sunlit day in July" (173) because "her fleeting victory had left in its wake a vast, echoing space, because she has taken on, for too long, a pitch of voice and a way of being that was not hers (176). This is the turning point in the novel since Ifemelu is beginning to reclaim her Nigerian identity and roots. Her decision to drop the American accent and maintain her natural hair is indeed an active comeback and cultural declaration of her Nigerian heritage. Although Ifemelu decides to hold on to her origin, leave her natural hair, and drop her American accent, she is still considered a hybrid character, and this is highlighted when she returns to Nigeria.

Due to Ifemelu's hybrid nature and the interweaving between the American and Nigerian cultures, when she returns to Nigeria, people claim that she has become Americanized. When Ifemelu arrives to Lagos in Nigeria, her old friend Ranyinudo picks her up and calls her "Americanah," and tells her, "You are looking at things with American eyes" (385). This shows how Ifemelu is displaced even in her homeland and that she is now a product of both the American and Nigerian cultures. Ifemelu cannot adapt quickly to her homeland when she returns, and it can be deduced that Ifemelu is placed in an in-between 
space, a third space. Ifemelu is "caught between not being American in America and not being Nigerian in Nigeria" and instead becomes a hybrid who occupies a "third space" (Asmarawati 2017, 178). Ifemelu has observed the American culture with an outsider's eye in the United States, and now Nigeria somehow also becomes foreign to her.

Ifemelu feels like a tourist in her own country; however, she also feels "guiltily grateful that she had a blue American passport in her bag. It shielded her from choicelessness. She could always leave; she did not have to stay" (Adichie 2017, 390). Towards the end of the novel, when Ifemelu returns to Nigeria, she attends a Nigerpolitian meeting with her friend Doris where "its just a bunch of people who have recently moved back, some from England, but mostly from the US" (405). During these meetings, the participants listed "the things that they missed about America," like soymilk and good customer service (408). These people who meet and talk about their experiences in their host countries are all considered to be hybrids and they all meet to share their experiences. Towards the end of the novel, it is apparent that Ifemelu is adjusting to Nigeria and finds a new identity; she becomes a hybrid of the two cultures she encountered. It also seems that Ifemelu returns to Nigeria with a more mature and strong stance. Obinze mentions that directly to Ifemelu and tells her, "You've changed. [...] You're more self aware. Maybe more guarded" (432-33). Ifemelu's hybridity is seen through a positive light, and Obinze tells her, "your blog also made me so proud. I thought: She's gone, she's learned and she's conquered" (433). Stuart Hall explains that migrants "are obliged to come to terms with the new cultures they inhabit, without simply assimilating to them and losing their identities completely," and that is exactly what Ifemelu does (1992, 310).

Obinze and Ifemelu's experiences abroad are very different. When Obinze migrates illegally to England, he realizes that the English society identifies him in a very different manner than the ways he has been familiar with in Nigeria, which is also the case with Jemu in The Inheritance of Loss. The Nigerian culture emphasizes the dominant position of men, always placing the male on a higher pedestal. However, when Obinze arrives to England, he becomes merely a Black man and loses all the gender privilege he once had in Nigeria. Obinze becomes the 'Other' due to his skin color, and all the advantages he was used to in Nigeria become useless in a society that defines masculinity in terms of whiteness. Due to his race, Obinze "approached his first job with irony: he was indeed abroad cleaning toilets, wearing rubber gloves and carrying a pail" (Adichie 2017, 236). Cleaning toilets in Nigeria is a role that is usually left for women since the female 
is always associated with the domestic sphere, however, as Obinze crosses geographical borders, his gender is perceived in a different manner due to his skin color. Bonvillain explains that "Obinze's position as a black man in England strips him from the social power he had in Nigeria, yet as this realization dawns on Obinze, he also begins to see the reason he even had social power was because of gender and class hierarchies in Nigeria" $(2016,31)$. Obinze's tried to become a hybrid and embrace both the English and Nigerian personas, however, he failed to do so due to his skin color and his illegal stance in England.

Aunt Uji, a minor character in Americanah, and Ifemelu's aunt, who immigrates to the United States after her husband dies, reacts to hybridity differently. She doesn't seem so keen on preserving her roots just like Jemu in The Inheritance of Loss, and she doesn't seem to appear as a hybrid like Ifemelu, Sai, or Saeed Saeed. Aunt Uju re-shapes her behavior completely in order to be accepted in the American society, and in the process, discards her roots completely. When Ifemelu first meets Aunt Uju in America, she realizes that "America had subdued her" (Adichie 2017, 110). Moreover, Ifemelu realizes that her aunt pronounces her own name "you-joo instead of oo-joo" and when Ifemelu asks her why she pronounces her name differently, Aunt Uju tells her, "It's what they call me" and then later tells her, "You are in a country that is not your own. You do what you have to do in order to succeed" $(104,119)$.

Aunt Uju completely disregards her roots just like Jemu in The Inheritance of Loss, and this is also evident through her relationship with her son, Dike. When Ifemelu meets Dike and speaks to him, Aunty Uju tells Ifemelu, "Please don't speak Igbo to him," and when Ifemelu asks why, Uju replies, "This is America. It's different" (109). Uju tries very hard to impersonate the Americans through her accent as well. When Dike takes an item from the shelf at the grocery store, she tells him:

'Dike, put it back' [...] with the nasal, sliding accent she puts on when she spoke to white Americans, in the presence of white Americans. Pooh-reet-back. And with the accent emerged a new persona, apologetic and self-abasing. She was overeager with the cashier. (108)

It is clearly evident that Aunt Uju is trying to exclude her Nigerian identity completely and she had "deliberately left behind something of herself, something essential, in a distant and forgotten place" (119). 
In relation to Homi Bhabha's concept of hybridity, all the characters in Desai's The Inheritance of Loss and Adichie's Americanah encounter overlaps between the West and their country of origin; however, their reaction to hybridity varies. Both novels depict the positive and negative outcomes of hybridity, and through the characters, the authors are able to explore how transnational identities are created and how individuals navigate cultural and national boundaries. In Desai's novel, Jemu wishes to eradicate his Indian heritage and chooses to mimic the West, Biju refuses to become Westernized and clings to his own heritage and roots, Sai does not choose any sides and lets both the Indian and the English cultures to penetrate her, and Saeed Saeed is considered a malleable character who adapts to his host country without letting go of his own origin and heritage. Both Saeed and Sai are the only flexible characters in the novel who consciously embrace their hybridity and their malleable identities. Through the analysis of the major characters in the novel, it is apparent that Desai tries to suggest that there are many obstacles to transnational mobility and hybridity, and that it does not necessarily end on a happy note; however, through the character of Sai, she also tries to highlight that embracing hybridity is often the best choice one can make. In Chimimanda Adichie's Americanah, Ifemelu adopts a dynamic identity when she crosses borders, whereas Aunt Uji, like both Biju and Jemu, completely resists hybridity and wants to feel rooted in only one location. William Moseley argues that "dwelling in two different places and cultures breeds hybridity and insight," but in the case of Jemu, Biju and Aunty Uji, dwelling in two different locations and cultures has a meager transformative potential because they refuse to embrace hybridity and choose fixity instead $(2014,5)$. The novels, together with their authors, are inherently border-crossers since they are capable of moving beyond the limits of a single national culture. Moving beyond essentialism becomes an incentive for creativity since the border-crosser no longer identifies with any binary concepts. Individuals such as Sai, Saeed, and Ifemelu become empowered and liberated due to their multifaceted personalities, their flexibility, and their malleability.

\section{Works Cited}

Adichie, Chimamanda Ngozi. 2017. Americanah. New York: Fourth Estate. Arabian, Soheila, and Vida Rahiminezhad. 2015. "Journey and Return: Visiting Unbelonging and Otherness in Adichie's Americanah." Journal UMP Social Sciences and Technology Management 3 (3): 536-41. 
Asmarawati, Cindera, et al. 2017. "Mimicry, Hybridity, and Ambivalence in Chimamanda Ngozi Adichie's Americanah and Purple Hibiscus." International Conference on Education and Science, no. 24, Universitas PGRI Yogyakarta, Jakarta (July): 170-82.

Bhabha, Homi K. 1994. The Location of Culture. New York: Routledge.

----- and Jonathon Rutherford. 1990. "The Third Space: Interview with Homi Bhabha." In Identity: Community, Culture, Difference, edited by Jonathon Rutherford, 207-21. London: Lawrence \& Wishart.

Bonvillain , Mary Margaret. 2016. "Shifting Intersections: Fluidity of Gender and Race in Chimamanda Ngozi Adichie's Americanah.” Diss. Ames, IA: Iowa State University.

Clingman, Stephen. 2012. The Grammar of Identity: Transnational Fiction and the Nature of the Boundary. London: Oxford University Press.

Dagnino, Arianna. 2013. "Transcultural Literature and Contemporary World Literature(s)." CLCWeb: Comparative Literature and Culture 15 (5): n. pag.

Dayal, Samir. 1996. "Diaspora and Double Consciousness." The Journal of the Midwest Modern Language Association 29 (1): 46-62.

Desai, Kiran. 2007. The Inheritance of Loss. London: Penguin Books.

Friedman, Susan Stanford. 2002. “'Border Talk, Hybridity, and Performativity." Eurozine 7 (June): 1-34.

----- 1998. Mappings: Feminism and the Cultural Geographies of Encounter. Princeton, NJ: Princeton University Press.

Gikandi, Simon. 2011. "Foreword: On Afropolitanism." In Negotiating Afropolitanism: Essays on Borders and Spaces in Contemporary African Literature and Folklore, edited by Jennifer Wawrzinek and J. K. S. Makokha, 910. Leiden: Brill.

Guignery, Vanessa. 2011. "Hybridity, Why It Still Matters." Hybridity: Forms and Figures in Literature and the Visual Arts, edited by Vanessa Guignery, Catherine Pesso-Miquel, and François Specq, 1-8. Newcastle: Cambridge Scholars Press. Gustafson, Per. 2001. "Roots and Routes: Exploring the Relationship between Place Attachment and Mobility." Environment and Behavior 33, no. 5 (September): 667-86.

Hall, Stuart. 1992. Modernity and Its Futures. The Question of Cultural Identity. London: Open University Press.

Hooda, Ambreen. 2014. "Could Fulfillment Ever Be Felt as Deeply as Loss?: A Postcolonial Examination of the West's Influence On India As Reflected by Kiran Desai's Portrayal of the Twentieth Century Female Education in The Inheritance of Loss." Diss. San Antonio, TX: Trinity University.

Hoogvelt, Ankie M. M. 2001. Globalization and the Postcolonial World: The New Political Economy of Development. London: Palgrave Macmillan. 
Kondali, Ksenija. 2018. "Migration, Globalization, and Divided Identity in Kiran Desai's The Inheritance of Loss." The Art of Words 62, no. 1 (February): 10116.

Kuortti, Joel, and Jopi Nyman. 2007. "Introduction: Hybridity Today." In Reconstructing Hybridity: Post-Colonial Studies in Transition, edited by Joel Kuortti and Jopi Nyman, 1-18. New York: Rodopi.

La Barbera, MariaCaterina. 2015. "Identity and Migration: An Introduction." In Identity and Migration in Europe: Multidisciplinary Perspectives, edited by MariaCaterina La Barbera, 1-16. New York: Springer.

Moore, David Chioni. 1994. "Routes: Alex Haley's Roots and the Rhetoric of Genealogy." Transition: An International Review 64 (Fall): 4-21.

Moseley, William. 2014. "Riffing on Adichie's Americanah: International Journeys, the Hybrid Life, and Thoughtful Engagement." Lecture, 1-7. September 1, 2014. Macalester College.

Nyamnjoh, Francis B. 2013. "Fiction and Reality of Mobility in Africa." Citizenship Studies 17 (6-7): 653-80.

Rushdie, Salman. 2003. Step Across This Line: Collected Nonfiction 1992-2002. London: Vintage.

Sabo, Oana. 2012. "Disjunctures and Diaspora in Kiran Desai's The Inheritance of Loss." The Journal of Commonwealth Literature 47 (3): 375-92.

Sackeyfio, Rose A. 2017. "Revisiting Double Consciousness and Relocating the Self in Americanah." In A Companion to Chimamanda Ngozi Adichie, edited by Ernest N. Emenyonu, 213-28. New York: James Currey.

Soja, Edward W. 2009. "Thirdspace Toward a New Consciousness of Space and Spatiality." In Communicating in the Third Space, edited by Karin Ikas and Gerhard Wagner, 49-61. New York: Routledge.

Speilman, David. 2010. “'Solid Knowledge' and Contradictions in Kiran Desai's The Inheritance of Loss." Critique: Studies in Contemporary Fiction 51, no. 1 (July): 74-89.

Spivak, Gayatri Chakravorty. 1990. "Strategy, Identity, Writing." In The PostColonial Critic: Interviews, Strategies, Dialogues, edited by Sarah Harasym, 3549. New York: Routledge.

Winden, Johan Bernard van der. 2015. "Food Practices and the Construction, Performance and Politics of Identity in Kiran Desai's The Inheritance of Loss.” Diss. Leiden: Leiden University. 